How to cite: Cailliez, S., Donati, F., Touchart, L., Bartout, P., Kapanen, G., Marzecova, A., Terasmaa, J., Koff, T., Vandel, E., Choffel, Q., Millot, C., Maleval, V., Qsair, Z. (2019) The Chemical Properties of Pond Sediments and the Operations of River Restoration. 2019 "Air and Water - Components of the Environment" Conference Proceedings, Cluj-Napoca, Romania, p. 189-196, DOI: 10.24193/AWC2019_19.

\title{
THE CHEMICAL PROPERTIES OF POND SEDIMENTS AND THE OPERATIONS OF RIVER RESTORATION
}

\author{
Simon CAILLIEZ ${ }^{1}$ 凹, Francesco DONATI ${ }^{1}$, Laurent TOUCHART ${ }^{l}$, Pascal $^{2}$ \\ BARTOUT ${ }^{l}$, Galina KAPANEN ${ }^{2}$, Agata MARZECOVA ${ }^{2}$, Jaanus \\ TERASMAA ${ }^{2}$, Tiiu KOFF ${ }^{2}$, Egert VANDEL $L^{2}$, Quentin CHOFFEL ${ }^{1}$, \\ Camille MILLOT ${ }^{3}$, Véronique MALEVAL ${ }^{3}$, Zoudiba QSAIR $^{I}$
}

\section{DOI: 10.24193/AWC2019_19}

\begin{abstract}
In France, in the last few years, a lot of ponds have been removed during operations of river restoration, remobilizing the sediments that had been deposited behind the dam over the years. Pond sediments are complicated mixtures predominantly consisting of rocks and soils particles from the watershed, atmospheric dust brought by winds, algae and organic remains or particles that were produced by processes in the water column, such as amorphous silica or calcite. Sediments "can be dressed" with chemical elements of various kinds, including pollutants that settle on the bottom of the ponds. It is therefore important to understand what types of substances can be found in pond and to understand the effect of operations of river restoration on water quality. We applied the X-ray fluorescence spectrometry (XRF), where sample is irradiated with X-rays from a radioactive source, which excites the elements in the sample and generates secondary fluorescent X-rays. Elements emit energy of unique wavelengths, which allows their qualitative and quantitative determination. Commonly, elements from atomic number $11(\mathrm{Na})$ to $92(\mathrm{U})$ can be detected. Using this methodology, analyses were made on sediments samples from a pond located in the centre of France: results show that the pond is relatively free of pollutants. Starting from this reference, we will think which substances can be remobilized after operations of rivers restoration.
\end{abstract}

Keywords: ponds, sediments, hydrosystems restoration, XRF, France

\section{INTRODUCTION}

Bodies of water can be considered as settling basins for all particles that are inside their perimeter and that settle on the bottom. Lake sediments can be of various kinds: fragments of rock or soil, dust carried by the wind, fragments of organic matter or particles created in the water column following physical-chemical processes (Cohen,

\footnotetext{
1 Laboratoire CEDETE, Université d'Orléans, France cailliez.simon@gmail.com fdonati90@gmail.com laurent.touchart@univ-orleans.fr

${ }^{2}$ Institute of Ecology, Tallinn University, Uus-Sadama5, Tallinn 10120, Estonia

${ }^{3}$ Laboratoire GEOLAB, Université de Limoges, France
} 
2003, Wetzel, 2001). During their journey, they can be covered with chemical elements of various kinds, including different polluting substances. So, bodies of water work as a filter that removes substances potentially harmful to aquatic environments.

Since the promulgation of Water Framework Directive 2000 (WFD 2000), many ponds in France have been suppressed during operations of river restorations. In fact, they are considered harmful for the aquatic ecosystems, as they would modify the liquid and solid flows, alter the physical and chemical properties of the watercourses and the transit of the organisms that live inside (Souchon \& Nicolas, 2011). The removal of the ponds leads to the remobilization of sediments deposited for centuries and chemical substances potentially harmful to the aquatic environments. It can cause the risk of serious pollution phenomena.

In the application of WFD 2000, the promulgation of Water and Aquatic Environment Law (LEMA, 2006), permit to enhance aquatic environment management in France. This law made common the vision that improvement of water quality depends on river restoration by dam deletion.

It is, therefore, necessary to undertake studies on the physico-chemical properties of sediments deposited on the bottom of the ponds, in order to understand and prevent the possible risks associated with river restoration. However, this kind of analysis are often expensive, time-consuming and complicated.

The objective of this article is to understand which substances may be in the substrate of a body of water, using X-ray fluorescence (XRF) spectroscopy, a methodology that seems to be effective for this kind study.

\section{STUDY SITE AND METHODS}

\subsection{Study site}

The sediment core was taken from the La Fontenille pond, situated in the municipality of Méry-ès-Bois, in the centre of France near the border of the geographical regions of Sologne and Pays Fort, in the historical province of Berry (Fig. 1). This pond is located on the Barangeon river, that flows in the south part of the forest and agricultural region called Sologne. The watershed is characterised by a geological context composed of sand with flints, sometimes argillaceous.

\subsection{Methods}

The sediment core was taken with a core drill by the CEDETE Lab from a rowboat. The retrieved $7 \mathrm{~cm}$ long core was freeze-dried (using the Telstar LyoAlfa 10 freeze-drier) and cut in seven one centimetre thick samples. The samples were sub-sampled for thermo-gravimetric (TGA) analysis (Precisa prepASH 340 system) and X-ray fluorescence (XRF) spectroscopy (PANalytical Epsilon 3-XL XRF spectrometer, Omnian software).

First of all, the core was freeze-dried (using the Telstar LyoAlfa 10 freeze-drier) and cut in seven equal parts. The TGA analysis was performed at the Institute of Ecology, Tallinn University. The content of organic matter and carbonates in 
sediment was estimated using the loss on ignition (LOI) analysis at $550{ }^{\circ} \mathrm{C}$ and 950 ${ }^{\circ} \mathrm{C}$, respectively (Boyle, 2000, 2001; Heiri et al., 2001).

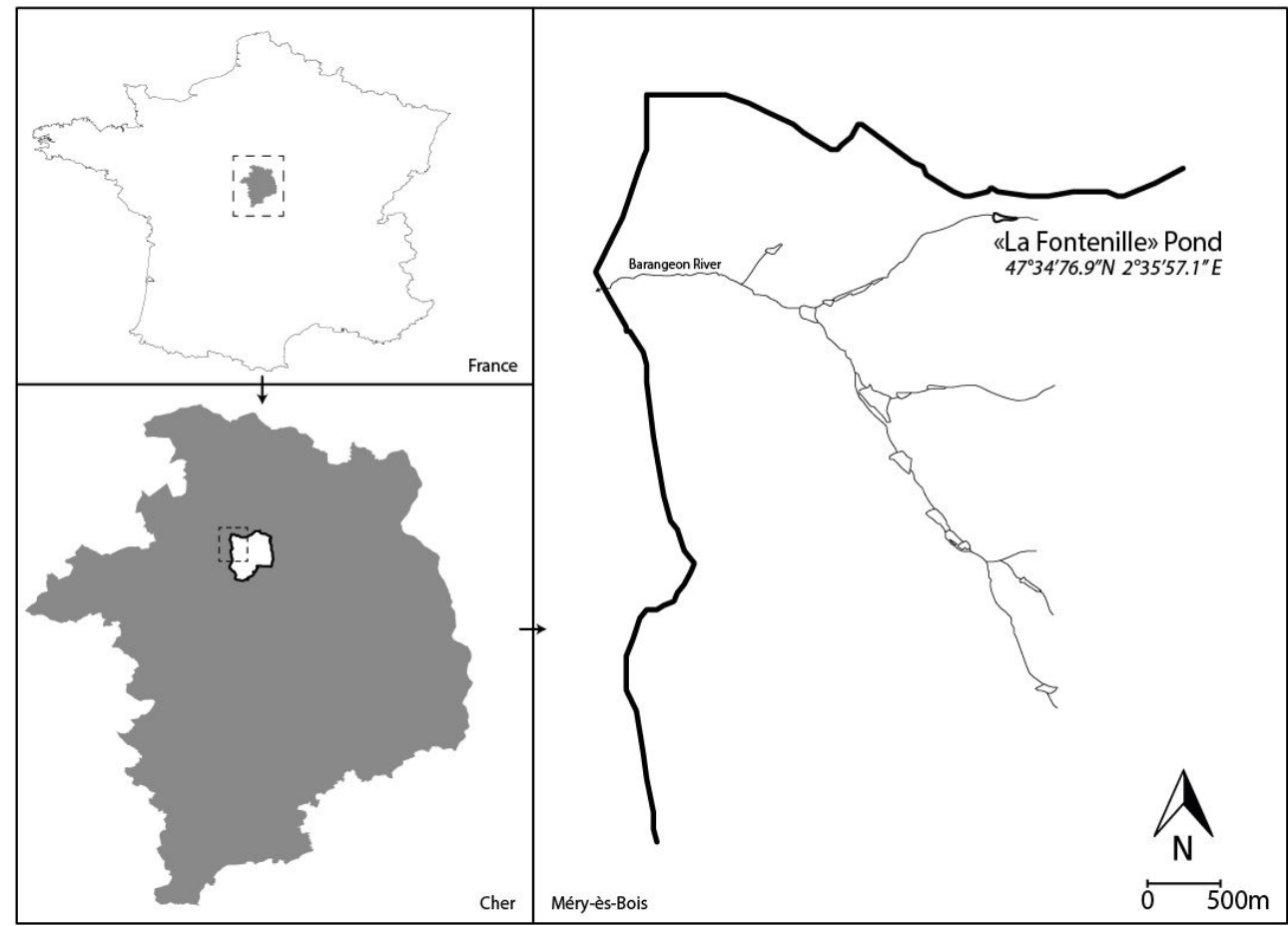

Fig. 1. Location of "La Fontenille" pond

The XRF analysis was performed at the Centre of Excellence in Health Promotion and Rehabilitation (TERE CC), Haapsalu College, Tallinn University according to the Boyle (2000) methodology. The sediment samples consisted of $2 \mathrm{~g}$ of dried and homogenized sediments. Analytical performance was calibrated with known reference standards. Mass attenuation correction used theoretical alpha coefficients, the calculation taking the organic matter concentration into account. The element data were presented as concentrations, $\mathrm{mg} \mathrm{g}^{-1}$ or ppm (Boyle et al., 2015).

\section{RESULTS}

Mean values of the lithological variables (organic matter, mineral matter, carbonat) for the La Fontenille pond sediments were obtained from the seven subsamples, as presented in Table 1.

The values for metal and other element concentrations, (in total of 26 elements, normalized to dry weight), varied in average from $0.01 \mathrm{mg} / \mathrm{g}$ for $\mathrm{As}, \mathrm{Br}, \mathrm{Ga}, \mathrm{Nb}$, and Th to $188.7 \mathrm{mg} / \mathrm{g}$ for Si (Table 1). 
Table 1. Content in chemical elements in a seven centimeters sedimentary core. Analysis were performed with ED-XRF (2014, Haapsalu College)

\begin{tabular}{|c|c|c|c|c|c|c|c|c|}
\hline \multirow{2}{*}{$\begin{array}{c}\text { Element } \\
(\%)\end{array}$} & \multicolumn{8}{|c|}{ Core depth in $\mathrm{cm}$} \\
\hline & $0 ; 1$ & $1 ; 2$ & $2 ; 3$ & $3 ; 4$ & $4 ; 5$ & $5 ; 6$ & $6 ; 7$ & Average \\
\hline Al & 3,493 & 3,587 & 3,563 & 3,466 & 3,703 & 3,431 & 3,493 & 3,534 \\
\hline As & 0 & 0,001 & 0,001 & 0,001 & 0 & 0,001 & 0,001 & 0,001 \\
\hline $\mathbf{B a}$ & 0,008 & 0,008 & 0,008 & 0,008 & 0,009 & 0,007 & 0,008 & 0,008 \\
\hline $\mathbf{B r}$ & 0,001 & 0,001 & 0,001 & 0,001 & 0,001 & 0,001 & 0,001 & 0,001 \\
\hline $\mathbf{C a}$ & 0,773 & 0,753 & 0,713 & 0,664 & 0,687 & 0,654 & 0,65 & 0,699 \\
\hline $\mathrm{Cr}$ & 0,004 & 0,004 & 0,004 & 0,005 & 0,005 & 0,005 & 0,005 & 0,005 \\
\hline $\mathrm{Cu}$ & 0,001 & 0,002 & 0,001 & 0,001 & 0,002 & 0,002 & 0,002 & 0,002 \\
\hline Fe & 2,061 & 2,058 & 2,115 & 2,089 & 2,21 & 2,07 & 2,321 & 2,132 \\
\hline Ga & 0,001 & 0,001 & 0,001 & 0,001 & 0,001 & 0,001 & 0,001 & 0,001 \\
\hline $\mathbf{K}$ & 0,995 & 0,978 & 1,009 & 1,009 & 1,061 & 1,016 & 1,009 & 1,011 \\
\hline Mn & 0,042 & 0,043 & 0,049 & 0,048 & 0,05 & 0,042 & 0,038 & 0,045 \\
\hline $\mathrm{Nb}$ & 0,001 & 0,001 & 0,001 & 0,001 & 0,001 & 0,001 & 0,001 & 0,001 \\
\hline Nd & 0,003 & 0,003 & 0,004 & 0,004 & 0,003 & 0,003 & 0,003 & 0,003 \\
\hline $\mathbf{N i}$ & 0,003 & 0,003 & 0,003 & 0,003 & 0,003 & 0,003 & 0,003 & 0,003 \\
\hline $\mathbf{P}$ & 0,169 & 0,173 & 0,176 & 0,171 & 0,175 & 0,16 & 0,188 & 0,173 \\
\hline $\mathbf{P b}$ & 0,004 & 0,003 & 0,003 & 0,003 & 0,004 & 0,003 & 0,004 & 0,004 \\
\hline $\mathbf{R b}$ & 0,005 & 0,005 & 0,005 & 0,005 & 0,006 & 0,005 & 0,005 & 0,005 \\
\hline $\mathbf{S}$ & & 0,047 & 0,037 & & & & & 0,042 \\
\hline $\mathbf{S i}$ & 18,581 & 17,94 & 18,677 & 18,583 & 20,591 & 18,996 & 18,725 & 18,87 \\
\hline $\mathbf{S r}$ & 0,005 & 0,005 & 0,005 & 0,005 & 0,005 & 0,005 & 0,005 & 0,005 \\
\hline Th & & & 0,001 & 0,001 & & & & 0,001 \\
\hline Ti & 0,381 & 0,374 & 0,393 & 0,38 & 0,398 & 0,38 & 0,385 & 0,384 \\
\hline $\mathbf{V}$ & 0,004 & 0,005 & 0,005 & 0,005 & 0,005 & 0,004 & 0,005 & 0,005 \\
\hline $\mathbf{Y}$ & 0,003 & 0,003 & 0,003 & 0,002 & 0,003 & 0,003 & 0,002 & 0,003 \\
\hline Zn & 0,008 & 0,008 & 0,008 & 0,008 & 0,008 & 0,008 & 0,008 & 0,008 \\
\hline $\mathbf{Z r}$ & 0,022 & 0,023 & 0,023 & 0,021 & 0,024 & 0,021 & 0,021 & 0,022 \\
\hline
\end{tabular}

\section{DISCUSSIONS}

\subsection{Potential and limits of XRF}

One of the main advantages of the XRF analysis is minimal sample preparation and pre-treatment which allows rapid analysis; simultaneous detection of multiple elements while preserving the sample material for other analyses.

Limitations of the method for natural materials like sediments, arise from spectral overlap, matrix absorption and enhancement effects, the proportion of organic matter 
and light elements and sample in homogeneity. All of this can affect the precision, accuracy, and sensitivity of the method.

XRF method can detect metals with ca. 1 PPM detection limit. Although other analytical methods have better detection limits and therefore are more suitable for detecting the elements present at low concentrations, several studies have been successful in using the XRF to detect changes in the atmospheric deposition of metals, both natural (De Vleeschouwer et al., 2009) and industrial (Renberg et al., 2001).

Furthermore, the XRF analysis is not fully automatic and requires suitable calibrations and matrix corrections that will account for the unmeasured organic matter component. However, the amount of studies that provide methodological improvements on how to account for these issues is on the rise (e.g. Boyle, 2000; De Vleeschouwer et al., 2011; Rydberg, 2014; Rydberg and Martinez-Cortizas, 2014).

Many of the alternative techniques require dissolution procedures that are both time-consuming and costly in terms of the acids or other reagents required. The overview of these analytical techniques and the limitations (the sample preparation, detection limits and work demand) have been in detail presented in reviews, for example by Boyle (2001) and Boyle et al. (2015).

\subsection{Substances in sediments}

The samples consist of light and organic-rich matrixes with a relatively similar composition. The potentially toxic heavy metals $(\mathrm{Cu}, \mathrm{Zn}, \mathrm{Pb}, \mathrm{Cr})$, were detected in very small quantities, close to the natural background or trace levels of Arsenic. Although only the first seven centimeters of the sediment column is analyse, the results show that the pond is free of any type of contamination from pollutants. Total $\mathrm{P}$ content is in average $1.7 \mathrm{mg} / \mathrm{g}$, but is slightly increases in the deeper sediment layers. Probably, the concentration of this element is attributable to the agricultural activities that exist in the watershed of the body of water.

\section{CONCLUSION}

Chemical analysis by Energy Dispersive X-Ray Fluorescence spectrometer permits to characterize pond conditions in a French representative watershed. This will permit the use of XRF analysis as a base for comparison of former ponds removed due to river restoration with still active ponds and also assess chemical processes caused by sediment remobilization.

Globally, these data can be used as a reference for a pond in the rural context. These conditions are due to watershed type, mainly covered with forests, farmlands and sparse population. It can be assumed that ponds located downstream of cities or industrial sites contain higher percentages of pollutants.

In the context of dam deletion, a study of sediment remobilization, concerning chemical and suspended matter exportation, will permit to increase our knowledge 
on impacts, as well as on the temporality and chemical behaviour of the water bodies after dam removal.

\section{ACKNOWLEDGEMENTS}

The authors would like to thank Professor Michel Meybeck for checking the results.

\section{REFERENCES}

1. Beckhoff B., Kanngießer B., Langhoff N., Wedell R. \& Wolff H., (2007), Handbook of practical X-ray fluorescence analysis. Springer Science \& Business Media.

2. Boyle J.F., (2000), Rapid elemental analysis of sediment samples by isotope source XRF. Journal of Paleolimnology, 23(2), 213-221.

3. Boyle J.F., (2001) 2001. Inorganic geochemical methods in palaeolimnology. In: Last $W M$, Smol JP (eds) Tracking environmental change using lake sediments, vol 2 ., Physical and geochemical methods Developments in paleoenvironmental research, Dordrecht, 83-141.

4. Boyle J.F., Chiverrell R. \& Schillereff D., (2015), . Lacustrine archives of metals from mining and other industrial activities - a geochemical approach. In Environmental Contaminants (121-159). Springer Netherlands.

5. Cohen A.S. (2003), Paleolimnology: the history and evolution of lake systems. Oxford University Press.

6. De Vleeschouwer F., Renson V., Claeys P., Nys K., \& Bindler R., (2011), Quantitative WD-XRF calibration for small ceramic samples and their source material. Geoarchaeology, 26(3), 440-450.

7. De Vleeschouwer F., Piotrowska N., Sikorski J., Pawlyta J., Cheburkin A., Le Roux G., Lamentowicz M., Fagel N. \& Mauquoy D., (2009), Multiproxy evidence of 'Little Ice Age' palaeoenvironmental changes in a peat bog from northern Poland. The Holocene, 19(4), 625-637.

8. Heiri O., Lotter A. F., \& Lemcke G., (2001), Loss on ignition as a method for estimating organic and carbonate content in sediments: reproducibility and comparability of results. Journal of Paleolimnology, 25, 101-110.

9. Renberg I., Bindler R. \& Brännvall M.L., (2001), Using the historical atmospheric lead-deposition record as a chronological marker in sediment deposits in Europe. The Holocene, 11(5), 511-516.

10. Rydberg J., (2014), Wavelength dispersive X-ray fluorescence spectroscopy as a fast, non-destructive and cost-effective analytical method for determining the geochemical composition of small loose-powder sediment samples. Journal of Paleolimnology, 52(3), 265-276.

11. Rydberg J. \& Martinez-Cortizas, A., (2014), Geochemical assessment of an annually laminated lake sediment record from northern Sweden: a multi-core, multi-element approach. Journal of paleolimnology, 51(4), 499-514.

12. Souchon, Y., \& Nicolas, V. (2011, Novembre). Barrages et seuils: principaux impacts environnementaux. ONEMA, CEMAGREF. 
13. Vörösmarty C.J., Meybeck M., Fekete B.M., Sharma K., Green P., Syvitski J.P.M, (2003), Anthropogenic sediment retention: major global impact from registered river impoundments, Elsevier, Global and Planetary Change 39, 169-190

14. Walling D.E., Owens P.N., Leeks G.J.L., (1998), The role of channel and floodplain storage in the suspended sediment budget of the Rover Ouse, Yorkshire, UK., Geomorphology. 22, 225-242.

15. Wetzel R.G., (2001), Limnology: lake and river ecosystems. Gulf Professional Publishing

16. Ziegler C.K. \& Nibset B.S. (1995), Long-Term Simulation of Fine-Grained Transport in Large Reservoir, Journal of Hydraulic Engineering 121(11). 
